\title{
An Analysis on Students' Grammatical Errors in Writing Degrees of Comparison
}

\author{
Oktya Putri Bungsu*, Afrianto Daud, Masyhur \\ Universitas Riau, Indonesia \\ *oktya997@gmail.com
}

\begin{tabular}{ll}
\hline Article Info \\
\hline Received $: 2020-06-04$ \\
Accepted : 2021-03-04 \\
Published $:$ 2021-03-05 \\
\hline
\end{tabular}

Key words: grammatical errors, error analysis, writing, degrees of comparison

\begin{abstract}
The research aims to analyze the types of errors that students made in writing degrees of comparison and find out the sources of the errors. This research is a mixed-method research, a combination of qualitative and quantitative methods within a single research project. Using cluster sampling, 25 third grade students of MTs Masmur Pekanbaru were chosen as the sample of this research. The instruments used to get the data are written tests and semi-structured interviews. The error analysis procedure was used to analyze the data, which includes process of identification, description, explanation, and evaluation of errors. Based on the process of identification and description, it was found that students committed 365 errors that were classified into four types of error: misformation $(60,27 \%)$, omission $(26,58 \%)$, addition $(6,85 \%)$, and misordering $(6,30 \%)$. This study also revealed that the sources of the errors are: intralingual transfer $(61,39 \%)$, communication strategy $(17,82 \%)$, interlingual transfer $(14,85 \%)$, and context of learning $(5,94 \%)$. Furthermore, the errors committed by students were reconstructed into the correct form as the evaluation. Therefore, several recommendations were given to the students such as trying to explore more learning sources like grammar books, English courses, or the internet to expand their knowledge of English grammar and to develop their writing ability. In line with that, it's important for teachers to adopt innovative methods of teaching with detailed explanations to encourage students in learning, especially in writing degrees of comparison, to prevent the errors that occur in the future.
\end{abstract}

\section{INTRODUCTION}

Writing can be defined as one of the productive skills to express ideas or thinking in a written form that can be the tool to communicate with other people. According to Nunan (2003), writing is the mental work of inventing ideas, thinking about how to express them, and organizing them into statements and paragraphs that will be clear to a reader. Furthermore, Richard and Renandya (2002) state that writing is the most difficult skill for the second language and foreign language learners. They claim that writing is not only generating and organizing ideas of our mind, but also translating these ideas into readable text.

Therefore, grammar ability is essential for students because it will support the mastery of writing skills. According to Swan (1998), grammar is the rule that says how words changed to show different meanings, and they combine into sentences. It means that grammar has a significant role in writing, as a good writing has to contain good grammar. McKay (1987) also states that students need to have a good grammar foundation to communicate effectively in English. Grammar has many components, and the degree of comparison is one of them. Degree of comparison refers to adjectives being written in different forms to compare one, two or more nouns which are words describing people, places, and things. According to the 2013 Curriculum, Degree of Comparison is included and taught at the second semester of the eighth grade of SMP/MTs. The degree of comparison may sound simple but actually has various 
grammatical rules. Moreover, the degree of comparison is widely used both in speaking and writing.

As a second language learner, it is inevitable that learners will make errors in their writing. Hendrickson (1987) mentioned that errors are signals that indicate an actual learning process taking place and that the learner has not yet mastered or shown a wellstructured competence in the target language. Dulay, Burt, \& Krashen (1982) also stated that errors are a flawed side of a learner's speech or writing. In other words, an error can be defined as a form of language which deviates from its standard. Although errors are bad, they can bring some benefit for students who will learn more from their own error, as well as for teachers because an error can tell how far the learner has progressed and what remains for the learner to learn. Saville-Troike (2006) said that the learners' errors are the windows into the language learners' minds because learners' errors indicate teachers to know about learners' language ability.

However, an error has many synonyms in English, such as mistake, wrong, incorrect, and untrue. Even though these words are synonyms, but in learning a language, they have different meanings, so it is important to differentiate them. The words of wrong, incorrect, and untrue, simply used to describe something that is not correct or when the learner is not right about something. Meanwhile, errors and mistakes are frequently mentioned in the learning process. Richard (1985) stated that mistake is made by a learner when caused by lack of attention, fatigue, carelessness, or other aspects of performance. On the other hand, an error is made by a learner when caused by lack of ability in the target language. In this case, only errors are significant to the process of language learning.

Moreover, it is important to investigate the errors that students made so that the students will be able to communicate effectively as well as to prevent the learners to make the same errors. According to Brown (1994), error analysis is a branch of applied linguistics where the teacher can observe, analyze, and classify errors that students made to reveal something of the system operating within the learner, which led to a surge of study of learners' errors. Dulay, Burt, \& Krashen (1982) stated that studying students' errors serves two major purposes; providing data that can be used to make the nature of the language learning process, and giving some hints to the teachers and curriculum developers which types of error that prevent the learners to communicate effective. So, error analysis is important because it enables the teacher to find the source or cause of errors and how to find the right treatment to decrease their students' errors.

\section{RESEARCH METHODOLOGY}

\section{Research Design}

This study is a mixed-method research project. According to Dornyei (2007), mixed-method research is a combination of qualitative and quantitative methods within a single research project. Likewise, Cresswell \& Plano-Cark (2011) stated that mixed-method research is a methodology for conducting research that involves collecting, analyzing, and integrating quantitative and qualitative research in a single study or a longitudinal program of inquiry. The purpose of this form of research is that both qualitative and quantitative data provide a better understanding of a research problem or issue than either research approach alone.

\section{Setting and Participants}

This study took place at MTs Masmur Pekanbaru which is located on Jl. Soekarno Hatta, Pekanbaru, Riau. The research data was collected and analyzed from November - January 2019. The population of this study is the students of the third grade of MTs Masmur Pekanbaru, in the academic year 2019/2020 which consists of 3 classes. Class A consists of 25 students, class B consists of 24 students, and class $\mathrm{C}$ consists of 25 students. To determine the sample of the 
research, cluster sampling technique was used and 25 students of third grade MTs Masmur Pekanbaru were selected.

\section{Data Collection and Data Analysis}

The data of this research were obtained from written tests and semi-structured interviews. Nitko (1983) defined a test as a systematic procedure for observing and describing one or more characteristics of person with the aid of either a numerical or category system In this research, the test consists of 20 questions in the form of cloze procedure and 10 questions in the form of essay. Meanwhile, the semi-structured interview is a qualitative data collection strategy in which the researcher asks informants a series of predetermined but open-minded questions (Given, 2008). The qualitative data from the interview and quantitative data from the test in this study were analyzed differently based on each instrument.

In analyzing the qualitative data, the procedure of error analysis proposed by Corder in Ellis and Barkhuizen (2008) was used. The procedure consists of several stages. The first stage is collecting data. During this stage, the evidence that indicated the grammatical errors were investigated in students' writing. The students were given an hour to complete the written test which consists of 20 items in the form of cloze procedure and ten items of an essay. After all students finished, the test was collected in order to be checked. The second stage is the identification of errors. The identification of errors involved a comparison between what learners have produced and what a native speaker would produce in the same context. The writer identified the error by circling the parts that were deviating from the standard grammatical rules. The third stage is the classification of error. In this stage, the number of errors was counted based on the error classification of Dulay, Burt, \& Krashen (1982), they are: omission, addition, misformation, and misordering. To get the quantitative result, the data were calculated using Microsoft Excel 2010. The fourth stage is the description of error. During this stage, it was specified how the forms produced by students differ from native speakers' counterparts. In short, this step aimed to describe why the words or sentences were identified as errors. The final stage is error evaluation. In this stage, the errors made by the students were reconstructed into the correct form. One of the purposes of error analysis is to help students in learning second language. In this case, the correction of errors is given according to nature and significance of errors, especially errors that affect communication and cause misunderstanding. After analyzing the errors made by students in writing degrees of comparison, the frequency of each error was presented in the form of tables and charts, and finally, the conclusion was drawn, and some recommendations were given.

Meanwhile, the qualitative data were analyzed using the descriptive qualitative method proposed by Sugiyono (2008). In collecting the data, open-ended questions that related to the topic that have been prepared before were asked to the students. The interview was recorded with a recording device, and the results of the interview are rewritten in a paper. After obtained the data, the data were analyzed. There are three steps to analyze data in descriptive qualitative research. Those steps are data reduction, data display, and conclusion drawing. First, the writer selected, identified, and focused on data that are considered important and give valuable information. Next, the data was displayed in the form of narrative text in order to be easier to understand. Last, the writer drew a conclusion.

\section{FINDINGS AND DISCUSSION}

\section{Types of Errors}

It was found that four types of errors were committed by students in writing degrees of comparison, they are: omission, addition, misformation, and misordering. The percentage of error can be seen in the table below: 
Table 1. The Types of Errors

\begin{tabular}{llll}
\hline No & Types of Error & Total of Errors & Percentage \\
\hline 1 & Omission & 97 & $97 / 365 \times 100 \%=26,58 \%$ \\
2 & Addition & 25 & $25 / 365 \times 100 \%=6,85 \%$ \\
3 & Misformation & 220 & $220 / 365 \times 100 \%=60,27 \%$ \\
4 & Misordering & 23 & $23 / 365 \times 100 \%=6,30 \%$ \\
\hline & Total & 365 & $100 \%$ \\
\hline
\end{tabular}

The table shows that there are 365 total errors made by the students in writing degrees of comparison with the most frequent errors were: 220 errors of misformation $(60,27 \%), 97$ errors of omission (26,58\%), 25 errors of addition $(6,85 \%)$, and 23 errors of misordering $(6,30 \%)$.

\section{Sources of Errors}

After identifying the data, this research also tried to explain the sources of errors made by students in writing degrees of comparison according to Brown's (1994) classification of source of errors, which are: interlingual transfer, intralingual transfer, communication strategy, and context of learning. In classifying the source of error, the writer also used the supporting data obtained from the semi-structured interview to strengthen the validity of this research.

Table 2. The Sources of Errors

\begin{tabular}{llll}
\hline No & Sources of Error & Total of Errors & Percentage \\
\hline 1 & Interlingual Transfer & 54 & $54 / 365 \times 100 \%=14,85 \%$ \\
2 & Intralingual Transfer & 226 & $226 / 365 \times 100 \%=61,39 \%$ \\
3 & Communication Strategy & 64 & $64 / 365 \times 100 \%=17,82 \%$ \\
4 & Context of Learning & 21 & $21 / 365 \times 100 \%=5,94 \%$ \\
\hline & Total & 365 & $100 \%$ \\
\hline
\end{tabular}

\section{DISCUSSION}

\section{Types of Error}

\section{Misformation}

Misformation is the most frequent errors made by the students in writing degrees of comparison, which has 220 with rate of $60,27 \%$ of errors. Misformation errors are characterized by the use of the wrong form of the morpheme or structure (Dulay, Burt, \& Krashen, 1982). This kind of error shows that students still having a hard time comprehending and applying English grammatical rules. Several cases of misformation errors are explained below:

a. "Cheatting is $\underline{\text { badder }}$ than getting a bad mark." (Committed by students 4, 5, 6, 9, 10, 15, $16,17,18,19,20,21,22,24, \& 25)$

In this sentence, the student wrote comparative form badder instead of worse. This error occurred because the students ignored the Degree of Comparison rules for irregular words. $\mathrm{Bad}$ is one of irregular form, they used regular form when irregular form is required.

b. "The purse is expensiver than the pencil case." (committed by students 11, 12, 13, 14, 22, \& 23)

In this sentence, the students wrote expensiver instead of more expensive. They ignore the grammatical rule of degree of comparison, that to compare adjective with two or more syllable, determiner more instead of suffix -er is used.

c. "English is easyer than History." (committed by students 1, 11, 12, 14, \& 17)

In this sentence, the students wrote easyer instead of easier. It is wrong because the grammatical rule of affixation, which is if a word ends in $-\mathrm{y}$ preceded by a consonant, then it change into $-\mathrm{i}$ before add the suffix. So, the correct form of comparative easy is easier. 
d. "English is the easiest one, and history is the difficultest one." (committed by students 2, 3, $11,12,13,22,23)$

In this sentence, the students wrote superlative form difficultest instead of most difficult. They ignore the grammatical rule of degree of comparison, that to write superlative form of adjective with two or more syllable, determiner most of suffix -est is used.

\section{Omission}

Omission error occurs when the learner omitted a necessary element of word. In other word, this kind of errors are characterized by the absence of an item that must appear in a well-formed utterance and the content of morphemes which should be in the correctly expression. This error shows that students are still influenced by their first language. There are 97 errors with rate $26,58 \%$.

1. "The horse is biger than the donkey." (committed by students $2.3,4,5,11,12,14,23$ )

In this sentence, the students wrote biger instead of bigger. When a monosyllable adjective that ends in a single consonant (expect $\mathrm{w}, \mathrm{x}$, and $\mathrm{z}$ ) changed into a comparison or superlative form, the final consonant is doubled before the affix. The students ignore it and omit the double " $\mathrm{g}$ " in bigger.

2. "Stone is heaver than cotton." (committed by students 4, 5, 6, 8, 9, 10, 15, 16, 17, 19, 20, $21,24,25)$

In this sentence, the students wrote heaver instead of heavier. When an adjective that ends in $-\mathrm{y}$ changed into a comparison or superlative form, the $-\mathrm{y}$ letter is changed into $-\mathrm{i}$ letter. The students omitted the $-\mathrm{y}$ instead of changed into $-\mathrm{i}$ before adding the affix.

3. "The ocean $\emptyset$ deeper than the sea." (committed by students $3,4,5,6,8,11,12,13,14,16$, $20,21,22)$

In this sentence, the students omitted the be -is. A comparative adjective can be placed after the verb to be to make a proper sentence. The suggested correction is "The ocean is deeper than the sea".

4. "Gold is more expensive $\emptyset$ Silver." (committed by students 22)

In this sentence, the student omitted the preposition "than". In a comparative sentence, than must be placed after the adjective. The suggested correction is "Gold is more expensive than Silver"

\section{Misordering}

In this research the writer found 23 errors of misordering which is $6,3 \%$ of all errors. Misordering error occurred when the student put an utterance in a wrong order. Several cases of misordering are explained below:

a. "The purse is expensive more than the pencil case." (committed by students 2,3 )

The student placed more after the adjective. The more should've been placed before the adjective to make it into comparative form. The suggested correction is "The purse is more expensive than the pencil case".

b. "The ocean deeper is than the sea." (committed by students 11, 13, 16, 20, 21, 22)

The students wrote deeper is instead of is deeper. The right order of an English sentences is adjective placed after $b e$. The suggested correction is "The ocean is deeper than the sea)

\section{Addition}

Addition error occurred when the students put an unnecessary element to their sentences. In this research, the writer found 25 this kind of errors which is $6,85 \%$ of all errors. The writer found that students tend to failed to delete certain item when needed in and that leads to double marking. Several cases of addition are explained below: 
a. "The city is wideer than the town." (committed by students 1,3 )

The students wrote "wideer" instead of "wider". If a monosyllable adjective that ends with "e" changed into comparative or superlative form, double marking should be omitted.

b. The pencil case is cheapper than the purse. (committed by students $6,8,9,10,15,16,17$, $1819,20,21,25)$

The students wrote "cheapper" instead of "cheap". They added unnecessary element in their sentence where this element is not applied in the target language.

\section{Sources of Error}

1. Intralingual Transfer

Intralingual transfer is the most frequent source of errors made by the students in writing degrees of comparison, which has 226 with rate $61.39 \%$ of errors. When students acquired a new rule of a language, they must save the data on their mind. However, if they failed applying the rule due to their lack in target language, an error occurred, this kind of error belongs to Intralingual Transfer. For example, "Stone is heavyer than cotton", the students who wrote this sentence ignore the grammatical rule of affixation, which is if a word ends in $-\mathrm{y}$ preceded by a consonant, then it change into $-\mathrm{i}$ before add the suffix.

Moreover, based on the interview, the students stated that degrees of comparison is hard to be understood both the usage and the form. Student 1 stated

"I personally think that this material (degrees of comparison) is hard to understand because it has different rules for different words, I can't remember all the rules".

In fact, there are so many forms of degrees of comparison, which are; adjective with one syllable, two syllables, more than two syllables, and irregular form of some adjectives that have different rules. Meanwhile, in the usage of degrees of comparison, students 4 stated:

"I'm still having hard time in differentiating comparative degree and superlative degree, it's because they almost look alike to each other".

Moreover, student 2 also stated:

"I think this material (degrees of comparison) is hard for me and all of my classmate, there may be only one or two smartest kid in the class that fully understands degrees of comparison".

Based on students' statement, according to third grade students of MTs Masmur Pekanbaru, degrees of comparison's rule is difficult to understand.

2. Communication Strategy

Communication Strategy is related to learning style. Learners usually try an effort to cross their message, but sometimes it can be error. The writer found $17,82 \%$ of errors caused by communication strategy. For example, many students wrote "Cheating is badder than getting a bad mark". These students applied the wrong rule for irregular adjective. According to student 2's statement, "I thought that adding -er or -more to construct a comparative form is applied to all words, I didn't remember about irregular or regular rules", this explained that the students has understood that adjectives have a change of form to construct a comparative sentence, but they only learned one rule and applied it to all adjectives that has different rules.

Based the interview, when asked about how their learning style in writing degrees of comparison is, student 7 stated 
"When I was given a task to write a degree of comparison sentence, I usually just follow the examples or the pattern provided in the book".

This statement explains that he/she tend to look at the examples of degrees of comparison sentence and follow the pattern, ignoring the different rule for different adjective. In line with this, student 4 stated:

"Because this material (degrees of comparison) has many rules, I have a hard time in memorizing all of it. So I need English book when writing degrees of comparison".

The writer concluded that students' learning style, such as memorizing and following one examples of sentence is influencing students' writing and becoming a source of errors.

\section{Interlingual Transfer}

Another cause of error is interlingual. It's natural that second language learners made errors due to his/her mother language interference. In this research, the writer found that students still get influenced by their mother language in writing sentences using degrees of comparison. There are $14,85 \%$ errors caused by Interlingual Transfer. For example, student 5 wrote on her/his paper "The pencil case is cheap than the purse". As we know, in Indonesian "than" means "daripada", so after the interview, it was found that the student thought that the sentence is already a comparison sentence without changing the adjective into comparison form.

Furthermore, even though the students' know that comparison in English and Indonesian is different, they still confused. Student 7 stated

"When I am told to write in English, I write the sentence in Indonesian first and then translate it to English. I usually use English-Indonesian dictionary when I face difficulty".

This statement explained that he/she got influenced by his/her mother language a lot. Likewise, student 8 stated

"Writing in English is difficult, because I barely know any vocabulary in English. I need the dictionary or English books to write".

This statement supported the conclusion that third grade students of MTs Masmur Pekanbaru still get influenced by their mother language in writing degrees of comparison.

4. Context of Learning

Context of Learning is the source of errors caused by the learners' misinterpretation of the teacher's explanation and textbook or an inappropriate pattern contextualization. The writer found 5,94\% errors caused by Context of Learning. For example student 2 wrote "The purse is expensive more than the pencil case". Later according to the student's interview, she/he stated "I've been told that more than one syllable adjective is using more instead of -er. But I don't really understand about the placement".

Furthermore, based on the interview, students stated that their teacher has explained about the material about degrees of comparison both the usage and the form, but the teacher's delivering way is too plain that they didn't get interested in the material. Student 8 stated 
"The teacher has taught the material clearly. But if I can be honest, the explanation about the material (degrees of comparison) is too plain and boring. It's hard to concentrate and understand when I got no motivation".

The student admitted that her/his motivation in learning English is low, so even though the teacher has taught them clearly they still found English, especially degrees of comparison, is boring and difficult to understand

According to the finding and data analysis, there are 365 errors made by students in writing degrees of comparison which was divided into four types of error, they are misformation (220 errors or 60,27\%), omission (97 errors or $26,58 \%$ ), misorder (23 errors or 6,30\%), and addition (25 errors or 6,85\%). Furthermore, there are also 4 sources of error, they are intralingual transfer (226 errors or 61,39\%), communication strategy (64 errors or 17,82\%), interlingual transfer (54 errors or 14,85\%), and context of learning (21 errors or 5,94\%). It can be understood that students still made many errors in writing degrees of comparison.

In general, the study's findings are similar to some other studies with the same topic, such as Mirnanda (2014) that found the dominant or the highest rate type of error made by students in writing degrees of comparison is misformation with $71,75 \%$. Moreover, Tambunan \& Nababan (2018) who focused on students' errors in writing degrees of comparison of adjective, also found that the highest rate of all error types is misformation with $43,28 \%$. It can be concluded that misformation is the dominant type of error occurred in students' writing, and it shows that students are still having a hard time comprehending and applying English grammatical rules in their writing.

However, there are also differences between the findings of this study and other studies with the same topic, such as Hidayatullah (2015) that found the dominant source of error made by students in writing degrees of comparison is Communication Strategy with 42,63\%, which was occurred due to students' strategies in overcoming the communication problem they found in writing a second language sentences. Meanwhile in this study, the dominant source of error is Intralingual Transfer with $61,39 \%$ which was caused by students' lack in target language's grammatical rules.

\section{CONCLUSIONS}

In Indonesia, according to Curriculum 2013, students of middle-high school are expected to be able to write degrees of comparison sentences. However, their English ability, especially in writing, is still below the expectation. This research is aimed at analyzing grammatical errors made by the third-grade students of MTs Masmur Pekanbaru in writing degrees of comparison.

Based on the data provided in the finding, it can be concluded that third-grade students of MTs Masmur Pekanbaru still made many errors in writing degrees of comparison. A total of 365 errors were found in students' writing of degrees of comparison. The errors were classified into four categories, they are misformation with 220 errors $(60,27 \%)$, omission with 97 errors (26,58\%), misordering with 23 errors (6,30\%), and addition with 25 errors $(6,85 \%)$. Generally, such errors occurred due to four types of source of errors, they are intralingual transfer with 226 errors $(61,39 \%)$, communication strategy with 64 errors $(17,82 \%)$, interlingual transfer with 54 errors $(14,85 \%)$, and context of learning with 21 errors $(5,94 \%)$.

\section{REFERENCES}

Brown, H. (1994). Principles of Language Learning and Teaching. Englewood Cliffs: NJ: Prentice Hall.

Cresswell, J., \& Plano-Cark, V. (2011). Designing and Conducting Mixed Methods Research 2nd Edition. Cambridge: University of Cambridge Press. 
Dornyei, Z. (2007). Research Methods in Applied Linguistics. Oxford: Oxford University Press.

Dulay, H., Burt, M., \& Krashen, S. (1982). Language Two. New York: Oxford University Press.

Ellis, R., \& Barkhuizen, G. (2008). Analyzing Learner Language. Oxford: Oxford University Press.

Given, L. (2008). The SAGE Encyclopedia of Qualitative Research Methods. SAGE Publications.

Hendrickson, J. (1987). Error Correction in Foreign Language Teaching: Recent Theory, Research, and Practice. Boston: Heinle \& Heinle.

Hidayatulloh. (2015). An Analysis on Students' Grammatical Error in Using Degrees of Comparison (A Case Study at the Second Graded Students MTs Al-Islamiyah, Kebon Jeruk). Unpublished: Syarif Hidayatullah State Islamic University.

McKay, S. (1987). Teaching Grammar: Form, Function and Technique. United Kingdom: Prentice Hall.

Mirnanda, Y. (2014). An Analysis on the Students' Errors in Using Degrees of Comparison of Adjectives. Unpublished: Syarif Hidayatullah State Islamic University.

Nitko, A. (1983). Educational Tests and Measurement: An Introduction. New York: Harcourt Brace Jovanovich.

Nunan, D. (2003). Practical English Language Teaching. Singapore: International Edition McGraw-Hill.

Richard, J. C., \& Renandya, W. A. (2002). Methodology in Language Teaching: An Anthology of Current Practice. UK: Cambridge University Press.

Richards, J. C. (1985). Error Analysis: Perspective of Second Language Acquisition. London: Longman Group.

Saville-Troike, M. (2006). Introducing Second Language Acquisition. Cambridge: C.U.P.

Sugiyono. (2008). Metode Penelitian Kuantitatif Kualitatif dan R\&D. Bandung: ALFABETA.

Swan, M. (1998). Practical English Usage. London: Oxford University Press.

Tambunan, B. H., \& Nababan, J. (2018). The Error of Using Degrees of Comparison in Adjectives. International Journal of English Literature and Social Sciences (IJELS), 116118. 